\title{
STAMBULAS KONVENCIJAS RATIFICĒŠANA EIROPAS SAVIENĪBAS PERSONĀ PRETĒJI VISU EIROPAS SAVIENİBAS DALĪBVALSTU PIEKRIŠANAI
}

\section{RATIFICATION OF ISTANBUL CONVENTION BY EUROPEAN UNION CONTRARY TO CONSENT OF ALL MEMBER STATES OF EUROPEAN UNION}

\author{
Viktorija Soṇeca, LL.M. \\ Latvijas Universitātes Juridiskās fakultātes doktorante
}

\begin{abstract}
Summary
In the words of the Venice Commission, "[t]he added value of the Istanbul Convention [..] is that it is the first European instrument to deal with violence against women and domestic violence in a comprehensive manner. It introduces new provisions requiring a specific institutional setup [..] and foresees concrete prevention measures [..]; protection measures [..] and - under substantive law civil, administrative and criminal law measures, as well as procedural safeguards for victims. It is also the first European instrument that links these phenomena expressly to harmful gender stereotypes." ${ }^{1}$

However, accession to the Istanbul Convention has provided the backdrop for considerable tension both amongst the Member States and in the European Union. On the one hand, the participation of the former has been characterized by divergent approaches, tensions and controversy. On the other hand, there has been an inter-institutional conflict about the signature and conclusion of the Istanbul Convention on behalf of the European Union. This conflict is about everything a European Union external relations lawyer would like to talk about, namely, competences, procedure, and political disagreement. At the time of writing, these issues are examined by the European Court of Justice after the European Parliament requested an opinion under Article 218(11) of the Treaty on the Functioning of the European Union.
\end{abstract}

Atslēgvārdi: Stambulas konvencija, Eiropas Savienības tiesības, valsts tiesības noslēgt starptautisko līgumu, suverenitāte.

Keywords: Istanbul Convention, European Union rights, rights of a state to conclude international agreement, sovereignty.

\footnotetext{
${ }^{1}$ Venice Commission Opinion 961/2019 "Opinion on the constitutional implications of the ratification of the Council of Europe Convention on Preventing and Combating Violence against Women and Domestic Violence (Istanbul Convention) (Armenia)". Council of Europe doc. CDLAD(2019)018, 14.10.2019. Pieejams: https://www.venice.coe.int/webforms/documents/?pdf=CDL-AD(2019)018-e.
} 


\section{Ievads}

Eiropas Savien̄iba (turpmāk - ES) kopumā parakstījusi tikai divus starptautiskos cilvēktiesību līgumus, t. i., Konvenciju par personu ar invaliditāti tiesībām (turpmāk - UNCRPD) ${ }^{2}$ un Eiropas Padomes Konvenciju par vardarbïbas pret sievietēm un vardarbỉbas gimenē novēršanu un apkarošanu (turpmāk - Stambulas konvencija). Stambulas konvencija tās satura dēl nenoliedzami ir starpdisciplināras analīzes vērta, tomēr šajā referātā tiks apskatīts nevis tās saturs pēc būtības, bet pavisam cits aspekts - lojālas sadarbības princips, kurš nostiprināts Līgumā par Eiropas Savienību (turpmāk - LES) 4. panta 3. punktā.

Diemžēl šādā kontekstā Stambulas konvencija Latvijā nav apskatìta, lai gan konkrētais jautājums ir ārkārtīgi nozīmīgs vēl jo vairāk tādẹl, ka, pirmkārt, Satversmes tiesā ierosināta lieta Nr. 2020-39-02 par atsevišķu Stambulas konvencijas pantu atbilstību Satversmei. ${ }^{3}$ Otrkārt, Eiropas Savienības Tiesa (turpmāk EST) ierosinājusi lietu Avis 1/19 Convention d'Istanbul, pamatojoties uz Eiropas Savienības Parlamenta lūgumu. Ši lieta izskatîta 2020. gada 6. oktobrī, bet generāladvokāta secinājumi pasludināti 2021. gada 11. martā, savukārt spriedums gaidāms 2021. gada jūnijā.

Lietā Avis 1/19 Convention d'Istanbul Eiropas Parlaments (turpmāk - Parlaments) lūdz EST sniegt atzinumu, uzdodot divus jautājumus. Pirmais jautājums ir par juridisko pamatu, uz kura pieņemts ES Padomes (turpmāk - Padome) lēmums par Stambulas konvencijas noslēgšanu ES vārdā. Savukārt otrais jautājums saistīts ar ES lēmuma noslēgt Stambulas konvenciju spēkā esamību, ja šis lēmums pieṇemts bez visu dalībvalstu kopējas vienošanās, ṇemot vērā, ka visas ES dalībvalstis nav vienprātīgi piekritušas uzṇemties šajā konvencijā noteiktās saistības ${ }^{4}$.

Uzsverams, ka uz šo brīdi Stambulas konvenciju parakstījušas visas ES dalībvalstis un ES. Tomēr Latvija ir viena no sešām ES dalïbvalstīm (Bulgārija, Čehija, Ungārija, Lietuva un Slovākija), kas Stambulas konvenciju nav ratificējušas. Ievērojot lojālas sadarbības principu, Padomei lēmumu par starptautiskā līguma noslēgšanu no ES puses būtu jāpieņem pēc tam, kad to atbilstoši savām nacionālajām procedūrām apstiprinājušas visas ES dalībvalstis. Vienlaikus, protams, jāpatur prātā, ka Līguma par Eiropas Savienības darbību (turpmāk - LESD) 218. panta 7. punktā noteikts, ka Padome lēmumus par starptautisko līgumu parakstī̌sanu un pien̦emšanu pēc vispārīga noteikuma var pieņemt ar kvalificētu

\footnotetext{
2 Padomes 26.11.2009. lēmums par to, lai Eiropas Kopiena noslēgtu Apvienoto Nāciju Organizācijas Konvenciju par personu ar invaliditāti tiesībām, OV L 23, 27.01.2010., 35., 36. lpp. Par pievienošanās procesu plašāk sk.: G. de Búrca. The European Union in the Negotiation of the UN Disability Convention, (2010) 35 ELRev 174; D. Ferri. The unorthodox relationship between the EU Charter of Fundamental Rights, the UN Convention on the Rights of Persons with Disabilities and secondary rights in the Courts in the Court of Justice case law on disability discrimination, (2020) 16 European Constitutional Law Review 275.

${ }^{3}$ Ierosināta lieta Nr. 2020-39-02 "Par Stambulas konvencijas 3. panta "c" punkta, 4. panta 3. punkta un 12. panta 1. punkta atbilstibu Latvijas Republikas Satversmes ievadam, 1., 99. un 110. pantam, 4. panta 4. punkta atbilstibu Latvijas Republikas Satversmes 91. pantam un 14. panta atbilstïbu Latvijas Republikas Satversmes 112. pantam".

${ }^{4}$ Eiropas Parlamenta iesniegtā lūguma EST sniegt atzinumu saskaņā ar LESD 218. panta 11. punktu kopsavilkums. Pieejams: http://curia.europa.eu/juris/document/document.jsf?text=\&docid=221362\&p ageIndex $=0 \&$ doclang $=L V \&$ mode $=1$ st $\&$ dir $=\&$ occ $=$ first $\&$ part $=1 \& c i d=6459274$.
} 
balsu vairākumu. Līdz ar to šajā referātā tiks apskatīta konkrētā Padomes rīcība, kā arī sekas, ja EST atzìtu, ka Padomes rīcỉba ir atbilstoša.

\section{Stambulas konvencija - vispārējs ieskats būtiskākajos tās aspektos šī referāta ietvaros}

Stambulas konvencijas teksts tapis, pateicoties ekspertu grupai Ad Hoc Committee on Preventing and Combating Violence against Women and Domestic Violence (turpmāk - CAHVIO) ${ }^{5}$, kas kopumā tikās deviṇas reizes. CAHVIO Stambulas konvencijas teksta projektu pabeidza 2010. gada decembrī, savukārt 2014. gada 1. augustā Stambulas konvencija stājās spēkā. Vienlaikus ar minētās konvencijas tekstu CAHVIO sagatavoja skaidrojošu materiālu par Stambulas konvenciju, t. i., tās saturu. ${ }^{6}$

Stambulas konvencijas mērķi noteikti tās 1. pantā, un, lai sasniegtu šos mērķus, konvencija paredz plašu pasākumu klāstu, kas aptver visdažādākās jomas. Piemēram, konvencijā ietverta nodaļa, kas saistīta ar migrāciju un patvērumu (plašāk skatīt Stambulas konvencijas VII nodaļu). Šajā nodaḷā cita starpā paredzēts, ka Stambulas konvencijas pusēm jāpieṇem normatīvie akti, kā arī jāveic citi pasākumi, kas nepieciešami, lai nodrošinātu, ka ar dzimumu saistīta vardarbība pret sievietēm tiek atzīta par vajāšanu 1951. gada 28. jūlija Konvencijas par bēgḷa statusu 1. panta A punkta 2) apakšpunkta izpratnē (Stambulas konvencijas 60. pants). Apsvērumi, kādēḷ Stambulas konvencijas pusēm būtu papildus jāpieṇem nacionālie normatīvie akti vai arī jāveic citi pasākumi, lai izpildītu šo prasību, atrodami izskaidrojošā materiālā.?

Lai arī, no vienas puses, šo apsvērumu mērḳis savā veidā ir saprotams, tomēr, no otras puses, valstis ir jau pievienojušās Konvencijai par bēgḷu statusu, tādèjādi attiecīgi izvēloties minēto konvenciju piemērot. Līdz ar to nav izprotams šīs tiesību normas, kas uzliek dubultu pienākumu, mērķis. Turklāt, kā to norāda ǵenerāladvokāts savos secinājumos, jau šobrīd ES tiesībās ir saskaņoti nosacījumi trešo valstu valstspiederīgajiem/bezvalstniekiem, lai tie varētu pretendēt uz bēgḷa statusu vai tādas personas statusu, kam nepieciešama starptautiskā aizsardzība. ${ }^{8}$

Tāpat Stambulas konvencija paredz uzraudzības mehānismu, kuram jāfunkcionē ar GREVIO un konvencijas dalïbvalstu komitejas (sastāv no konvencijas dalībvalstu pārstāvjiem) starpniecību. Minētajai komitejai jāievēl GREVIO locekḷi, kā arī jāapstiprina GREVIO rekomendācijas, kas adresētas Stambulas konvencijas pusēm. Savukārt GREVIO uzdevumā ietilpst nodrošināt Stambulas konvencijas efektīvu noteikumu īstenošanu (plašāk GREVIO uzraudzības funkcijas un pilnvaras izklāstītas Stambulas konvencijas IX nodaḷā).

Tomēr jāuzsver, ka uz ES, gluži tāpat kā uz jebkuru citu konvencijas pusi, attieksies uzraudzības mehānisms, t. i., tas attieksies uz visām ES iestādēm,

\footnotetext{
${ }^{5}$ Documents on the negotiations are available here: https:/www.coe.int/en/web/istanbul-convention/ cahvio.

${ }^{6}$ Explanatory Report to the Council of Europe Convention on preventing and combating violence against women and domestic violence Istanbul of 11 May 2011. Pieejams: https://rm.coe.int/16800d383a.

7 Ibid.

${ }^{8}$ EST 18.12.2014. spriedums lietā C-542/13 M’Bodj, 44. punkts; Ģenerāladvokāta 11.03.2021. secinājumi lietā Avis 1/19, 110. punkts.
} 
struktūrām, birojiem un aǵentūrām. ${ }^{9}$ Tas tā ir, jo ES nevar izslēgt no Stambulas konvencijas piemērošanas jomas ES iestādes, struktūras, birojus un aǵentūras. Tomēr interesanti, ka Eiropas Komisija (turpmāk - Komisija) savos priekšlikumos vispār nav aplūkojusi minēto, kā arī nav vērtējusi šo jautājumu, lai gan tas skar pienākumus, kurus faktiski ES uzṇemsies un kuri būs attiecināmi uz tās iestādēm, struktūrām, birojiem un aǵentūrām. Šo jautājumu nav aktualizējusi arī Padome, lai gan, piemēram, UNCRPD gadījumā ES iesniedza deklarāciju, kurā norādīts uz ES un tās dalībvalstu kompetenču sadali un attiecīgi UNCRPD piemērošanas apjomu, pirms ES dalībvalstis izšķīrās ratificēt minēto konvenciju. ${ }^{10}$ Stambulas konvencijas gadījumā norādītais nav darīts. Tas vēl vairāk apliecina, ka konkrētais aspekts nav vērtēts, pieņemot lēmumu pievienoties Stambulas konvencijai, un mudina domāt, ka Stambulas konvencija ir sasteigta un vēl ir daudz neskaidru un neatrisinātu jautājumu, uz kuriem nav rastas precīzas atbildes.

Tāpat norādāms, ka, lai gan Stambulas konvencija principā izslēdz atrunas ${ }^{11}$, tomēr tajā pašā laikā tajā paredzēti daži izṇēmumi. Respektīvi, Stambulas konvencijas pusēm tiek saglabātas tiesības nepiemērot vai tikai īpašos gadījumos/apstāklos piemērot noteikumus, kurus paredz atsevišķi Stambulas konvencijas panti. ${ }^{12}$ Turklāt ikviena valsts vai ES var paziņot, ka tā saglabā tiesības kriminālsodu vietā paredzēt citus sodus par Stambulas konvencijas 33. un 34. pantā minētajiem noziedzīgajiem nodarījumiem. Šādas atrunas ir spēkā piecus gadus, tomēr tās var pagarināt vai arī atsaukt. ${ }^{13}$

Pašlaik Stambulas konvenciju parakstījušas 34 valstis, ${ }^{14}$ no kurām 22 ir izteikušas atrunas un/vai deklarācijas. ${ }^{15}$ Lai gan ES un tās dalībvalstis ir parakstījušas Stambulas konvenciju, tomēr to pieeja minētajai konvencijai un izpratne par to l̦oti atšķiras. Sešas dalībvalstis vēl nav ratificējušas Stambulas konvenciju (Bulgārija, Čehija, Ungārija, Latvija, Lietuva un Slovākija), savukārt Polija paziṇojusi par savu nodomu vispār izstāties no parakstījušo valstu pulka. ${ }^{16}$ Lielākā daḷa ES dalībvalstu

9 See recital 7 to the preambles to Council Decision (EU) 2017/865 and Council Decision (EU) 2017/866.

${ }^{10}$ Convention on the Rights of Persons with Disabilities. STATUS AS AT : 03-03-2021 09:15:27 EDT. Pieejams: https://treaties.un.org/Pages/ViewDetails.aspx?src=TREATY\&mtdsg_no=IV-15\&chapter=4\&clang=_ en\#EndDec.

11 "Atruna" - vienpusējs paziņojums jebkādā formulējumā, ko veic valsts, parakstot, ratificējot, pieņemot, apstiprinot vai pievienojoties līgumam, tādējādi izsakot nodomu izslēgt vai mainìt konkrētu līguma noteikumu tiesiskās sekas un to piemērošanu attiecīgajā valstī (Vīnes konvencijas par starptautisko līgumu tiesībām 2. panta 1. punkta d) apakšpunkts).

12 Stambulas konvencijas 30. panta 2. punkts, 44. panta 1. punkta e) apakšpunkts, 3. un 4. punkts, 55. panta 1. punkts kopsakarā ar 35. pantu par maznozīmīgiem pārkāpumiem, 58. pants kopsakarā ar 37., 38. un 39. pantu, kā arī 59. pants.

13 Stambulas konvencijas 78. un 79. pants.

14 Albānija, Andora, Austrija, Beḷgija, Bosnija un Hercegovina, Horvātija, Kipra, Dānija, Igaunija, Somija, Francija, Gruzija, Vācija, Griek̦ija, İrija, Itālija, Luksemburga, Malta, Monako, Melnkalne, Nīderlande, Ziemeḷmaḳedonija, Norvēgija, Polija, Portugāle, Rumānija, Sanmarīno, Serbija, Slovēnija, Spānija, Zviedrija, Šveice un Turcija. Pieejams: https://www.coe.int/en/web/conventions/full-list/-/conventions/treaty/210/ signatures.

15 Serbija, Rumānija, Polija, Ziemel̦maķedonija, Monako, Malta, Latvija, Īrija, Andora, Armēnija, Zviedrija, Šveice, Slovēnija, Somija, Francija, Gruzija, Vācija, Grieḳija, Horvātija, Kipra, Čehija, Dānija. Pieejams: https://www.coe.int/en/web/conventions/full-list/-/conventions/treaty/210/signatures.

16 Poland Announces Withdrawal from "Harmful” Istanbul Convention. 28.07.2020. Pieejams: https://exit. al/en/2020/07/28/poland-announces-withdrawal-from-harmful-istanbul-convention/. Sk. arī: https:// www.euronews.com/2020/07/27/istanbul-convention-poland-s-plan-to-quit-domestic-violence-treatycauses-concern. 
izteikušas atrunas par dal̦u no Stambulas konvencijas noteikumiem (Latvija, Lietuva, Horvātija, Kipra, Čehijas Republika, Dānija, Somija, Francija, Vācija, Grieķija, Īrija, Malta, Nīderlande, Polija, Rumānija, Slovākijas Republika, Spānija un Zviedrija).

Šo atrunu tvērumi ES dalībvalstīs atšķiras. Piemēram, Latvijas atruna ir par tiesībām nepiemērot Stambulas konvencijas 55. panta 1. punktu attiecībā uz 35. pantu saistībām ar noziedzīgajiem nodarījumiem, turpretī İrija paturējusi tiesības nepiemērot Stambulas konvencijas noteikumus, kas izriet no Stambulas konvencijas 30. panta 2. punkta un 44. panta. ${ }^{17}$ Vienlaikus, piemēram, Latvija un Lietuva paziņojušas, ka Stambulas konvenciju piemēros atbilstoši savu valstu konstitūciju noteikumiem un saskaṇā ar principiem, kas izriet no šīm konstitūcijām. ${ }^{18}$

Tāpat starp dalībvalstīm pastāv domstarpības par citu valstu deklarācijām. Piemēram, Austrija izteikusi oficiālu iebildumu par Polijas deklarācijas nesaderību ar Stambulas konvencijas mērḳi, ņemot vērā šīs deklarācijas vispārējo formulējumu, t. i., Austrijas ieskatā, no tā nevar skaidri izprast, cik lielā mērā Polija piemēros noteikumus, kas izriet no Stambulas konvencijas. ${ }^{19}$ Lai gan tajā pašā laikā uzsverams, ka Polija, tieši tāpat kā Latvija un Lietuva, ir norādījusi, ka tā piemēros Stambulas konvenciju atbilstoši savas konstitūcijas noteikumiem un no tās izrietošiem principiem. ${ }^{20}$

17 Reservations and Declarations for Treaty No. 210 (Ireland). Pieejams: https://www.coe.int/en/web/conventions/full-list/-/conventions/treaty/210/declarations?p_auth=yCy1070P\&_coeconventions_WAR_coeconventionsportlet_enVigueur=false\&_coeconventions_WAR_coeconventionsportlet_codeNature=2\&_coeconventions_WAR_coeconventionsportlet_searchBy=state\&_coeconventions_WAR_coeconventionsportlet_codePays=IRE

18 Reservations and Declarations for Treaty No. 210 (Latvia). Pieejams: https://www.coe.int/en/web/ conventions/full-list/-/conventions/treaty/210/declarations?p_auth=yCy1070P\&_coeconventions_ WAR_coeconventionsportlet_enVigueur=false\&_coeconventions_WAR_coeconventionsportlet_codeNature=2\&_coeconventions_WAR_coeconventionsportlet_searchBy=state\&_coeconventions_WAR_coeconventionsportlet_codePays=LAT; deklarācija: https:/www.coe.int/en/web/conventions/full-list/-/ conventions/treaty/210/declarations?p_auth=yCy1070P\&_coeconventions_WAR_coeconventionsportlet_enVigueur=false\&_coeconventions_WAR_coeconventionsportlet_codeNature $=10 \&$ \&_coeconventions_WAR_coeconventionsportlet_searchBy=state\&_coeconventions_WAR_coeconventionsportlet_codePays=LAT. Reservations and Declarations for Treaty No. 210 (Lithuania). Pieejams: https://www. coe.int/en/web/conventions/full-list/-/conventions/treaty/210/declarations?p_auth=yCy1070P\&_coeconventions_WAR_coeconventionsportlet_enVigueur=false\&_coeconventions_WAR_coeconventionsportlet_codeNature $=10 \&$ \&coeconventions_WAR_coeconventionsportlet_searchBy=state\&_coeconventions_WAR_coeconventionsportlet_codePays=LIT.

19 Reservations and Declarations for Treaty No. 210 (Austria). Pieejams: https://www.coe.int/en/web/conventions/full-list/-/conventions/treaty/210/declarations?p_auth=yCy1070P\&_coeconventions_WAR_coeconventionsportlet_enVigueur=false\&_coeconventions_WAR_coeconventionsportlet_codeNature $=6 \&$ _coeconventions_WAR_coeconventionsportlet_searchBy=state\&_coeconventions_WAR_coeconventionsportlet_codePays=AUS.

${ }^{20}$ Reservations and Declarations for Treaty No. 210 (Poland). Pieejams: https://www.coe.int/en/web/ conventions/full-list/-/conventions/treaty/210/declarations?p_auth=DotyhJzR\&_coeconventions_WAR_ coeconventionsportlet_enVigueur=false\&_coeconventions_WAR_coeconventionsportlet_codeNature $=10 \&$ \&_oeconventions_WAR_coeconventionsportlet_searchBy=state\&_coeconventions_WAR_coeconventionsportlet_codePays=POL. 
Arī Nīderlande ${ }^{21}$, Zviedrija ${ }^{22}$ un Somija ${ }^{23}$ ir iebildušas pret Polijas deklarāciju, pamatojoties uz līdzīgiem pamatiem, tādējādi apšaubot Polijas apṇemšanos izpildìt saistības, kuras nosaka Stambulas konvencija. Īpaši Somija norādijusi, ka Polijas deklarācija nav saderīga ar vispārējo principu, ka puse nedrīkst atsaukties uz savu valsts tiesību aktu noteikumiem kā attaisnojumu līgumsaistību neizpildei. ${ }^{24} \mathrm{Mine \overline {- }}$ tais noteikts Vīnes konvencijas par starptautisko līgumu tiesībām 27. pantā. Tomēr šajā sakarā uzsverams, ka šìs pašas valstis nav iebildušas par Latvijas un Igaunijas deklarācijām.

Tādējādi secināms, ka ES dalībvalstīm ir dažādas pieejas un izpratnes par Stambulas konvenciju, kas ir krasā pretrunā, piemēram, ar UNCRPD, par kuru neviena ES dalībvalsts nebija iesniegusi deklarāciju vai atrunu. Tāpat redzams, ka ES dalîbvalstu starpā nav vienotas izpratnes par to, kā Stambulas konvencijas būtu jāpiemēro vai jāinterpretē. Lìdz ar to vēl jo aktuālāks kḷūst jautājums par ES rīcības, pievienojoties Stambulas konvencijai bez visu tās dalībvalstu piekrišanas, saderību ar Vīnes konvencijas par starptautisko līgumu tiesībām 6. pantā noteikto, ka katrai valstij ir tiesības un brīvība noslēgt starptautiskos līgumus.

\section{Atzinuma pieprasijuma priekšvēsture un priekšmets}

Saskaṇā ar LES 13. panta 2. punktu katra ES iestāde darbojas atbilstoši tai Pamatlīgumos (LES un LESD) noteiktajām pilnvarām. Kā to atzinusi EST, noteikumi, kādā veidā ES iestādes pieņem lēmumus, paredzēti Pamatlīgumos un nav ne ES dalībvalstu, ne arī pašu ES iestāžu ziṇā. ${ }^{25}$ Minētais nozīmē, ka ES iestādēm jādarbojas atbilstoši savām pilnvarām, ievērojot procedūru, kas noteikta Pamatlīgumos, pieņemot attiecīgos lēmumus.

Vispārēja procedūra starptautisku nolīgumu apspriešanai un parakstī̌sanai noteikta LESD 218. pantā. Padomei saskaṇā ar minētās tiesību normas 5. un 6. punktu pēc Komisijas priekšlikuma jāpieņem lēmums, ar kuru tiek sniegta aṭ̂auja parakstīt nolīgumu un vajadzības gadījumā - to provizoriski piemērot līdz brīdim, kad tas stājas spēkā. ES dalībvalstīm šāda lēmuma pieņemšanā nav paredzēta nekāda kompetence. Tāpat Padomei jāpieņem lēmums par nolīguma noslēgšanu

${ }^{21}$ Reservations and Declarations for Treaty No. 210 (Netherlands). Pieejams: https://www.coe.int/en/ web/conventions/full-list/-/conventions/treaty/210/declarations?p_auth=yCy1070P\&_coeconventions_ WAR_coeconventionsportlet_enVigueur=false\&_coeconventions_WAR_coeconventionsportlet_codeNature=6\&_coeconventions_WAR_coeconventionsportlet_searchBy=state\&_coeconventions_WAR_coeconventionsportlet_codePays=NET.

22 Reservations and Declarations for Treaty No. 210 (Sweden). Pieejams: https://www.coe.int/en/web/conventions/full-list/-/conventions/treaty/210/declarations?p_auth=yCy1070P\&_coeconventions_WAR_coeconventionsportlet_enVigueur=false\&_coeconventions_WAR_coeconventionsportlet_codeNature=6\&_coeconventions_WAR_coeconventionsportlet_searchBy=state\&_coeconventions_WAR_coeconventionsportlet_codePays=SWE.

${ }^{23}$ Reservations and Declarations for Treaty No. 210 (Finland). Pieejams: https://www.coe.int/en/web/conventions/full-list/-/conventions/treaty/210/declarations?p_auth=yCy1070P\&_coeconventions_WAR_coeconventionsportlet_enVigueur=false\&_coeconventions_WAR_coeconventionsportlet_codeNature=6\&_coeconventions_WAR_coeconventionsportlet_searchBy=state\&_coeconventions_WAR_coeconventionsportlet_codePays=FIN.

${ }^{24}$ Corten O. and Klein P. (eds.). The Vienna Conventions on the Law of Treaties. A Commentary. OUP, 2011, pp. 443-445.

25 Case C-28/12 Commission v. Council, EU:C:2015:282, paragraph 42 and case law cited. 
pēc nolīguma sarunu vadìtāja priekšlikuma, ko Padome dara ar kvalificētu balsu vairākumu saskaṇā ar LESD 218. panta 8. punkta pirmo dalı. ${ }^{26}$

Tomēr šajā kontekstā norādāms, ka, lai gan Komisija piedalījās CAHVIO sanāksmēs, ${ }^{27}$ tā nebija iesniegusi priekšlikumu, lai Padome pieṇemtu lēmumu un ieceltu Komisiju sākt sarunas ES vārdā, kā arī Komisija nebija saṇēmusi akceptu no Padomes piedalīties CAHVIO sanāksmēs ES vārdā. Tādējādi no minētā nav saprotams, uz kāda pamata Komisija ir piedalījusies šajās sanāksmēs.

Norādītais, protams, vedina domāt arī par to, ka Komisija šajās sanāksmēs piedalijusies, balstoties uz LES 17. panta 1. punktu, kas paredz, ka Komisija īsteno ES ārējo pārstāvību, tomēr minētais tālāk rakstā netiks aplūkots, jo atrodas ārpus tā robežām, lai gan šis aspekts noteikti ir turpmākas izpētes vērts.

Kopumā Komisija 2016. gada 4. martā virzīja divus priekšlikumus Padomes lēmumiem par Stambulas konvencijas parakstīšanu ${ }^{28}$ un noslēgšanu ${ }^{29}$ ES vārdā. Pirmajā lēmumā kā juridiskais pamats norādīts LESD 218. panta 5. punkts, bet otrajā - LESD 218. panta 6. punkta a) apakšpunkts. Savukārt saistībā ar materiālo juridisko pamatu Komisija izvēlējās LESD nodaḷu par tiesu sadarbību krimināllietās un atsaucās uz LESD 82. panta 2. punktu ${ }^{30}$ un 84. pantu. ${ }^{31}$ Tomēr Padome no Komisijas priekšlikumiem atkāpās, ${ }^{32}$ izmainot juridisko pamatu, t. i., Lēmuma 2017/856 pamatā ir LESD 82. panta 2. punkts un 83. panta 1. punkts. ${ }^{33}$ Savukārt Lēmuma 2017/866 pamatā ir LESD 78. panta 2. punkts, kas paredz pieņemt pasākumus kopējai Eiropas patvēruma sistēmai. Minētais norāda, ka Komisijai un Padomei nav vienotas izpratnes par Stambulas konvencijas tvērumu, tāpēc Parlaments lūdza EST sniegt atzinumu saskaṇā ar LESD 218. panta 11. punktu (lieta Avis 1/19 Convention d'Istanbul).

${ }^{26}$ For an alaysis of these procedures, see A. Dashwood in A. Dashwood, M. Dougan, B. Rodger, E. Spaventa and D. Wyatt, Wyatt and Dashwood's European Union Law (6 $6^{\text {th }}$ ed., 2011) 936 et seq and P. Koutrakos, EU International Relations Law (2nd ed, 2015) Ch. 4.

${ }^{27} \operatorname{COM}(2016) 109$ final. Proposal for a Council Decision on the conclusion, by the European Union, of the Council of Europe Convention on preventing and combating violence against women and domestic violence. Pieejams: https:/www.europarl.europa.eu/cmsdata/115844/council-decision.pdf. $\operatorname{COM}(2016) 111$ final Proposal for a Council Decision on the signing, on behalf of the European Union, of the Council of Europe Convention on preventing and combating violence against women and domestic violence., p. 2. Pieejams: https://data.consilium.europa.eu/doc/document/ST-6695-2016-INIT/ en/pdf.

${ }^{28} \operatorname{COM}(2016) 111$ final.

${ }^{29} \operatorname{COM}(2016) 109$ final.

30 “Tiktāl, cik tas ir nepieciešams, lai veicinātu tiesas spriedumu un lēmumu savstarpēju atzišanu, kā arī policijas un tiesu iestāžu sadarbību krimināllietās, kam ir pārrobežu aspekts, Eiropas Parlaments un Padome, pieņemot direktīvas saskaņā ar parasto likumdošanas procedūru, var noteikt minimālos noteikumus. Šādos noteikumos n̦em vērā dalībvalstu tiesību tradīciju un tiesību sistēmu atškirīības.”

31 "Eiropas Parlaments un Padome saskaṇā ar parasto likumdošanas procedūru var noteikt pasākumus, lai veicinātu un atbalstītu dalībvalstu rīcību noziedzīgu nodarījumu novēršanas jomā, neiekḷaujot šādos pasākumos dalïbvalstu normatīvo aktu tuvināšanu."

32 Council Decision (EU) 2017/865 of 11 May 2017 on the signing, on behalf of the European Union, of the Council of Europe Convention on preventing and combating violence against women and domestic violence with regard to matters related to judicial cooperation in criminal matters, [2017] OJ L 131/11; Council Decision (EU) 2017/866 of 11 May 2017 on the signing, on behalf of the European Union, of the Council of Europe Convention on preventing and combating violence against women and domestic violence with regard to asylum and non-refoulement, [2017] OJ L 131/13.

33 "Eiropas Parlaments un Padome, pieņemot direktīvas saskaṇā ar parasto likumdošanas procedūru, var paredzēt noteikumu minimumu noziedzīgu nodarījumu un sankciju definēšanai attiecībā uz īpaši smagiem noziegumiem ar pārrobežu dimensiju, kas saistīta ar šādu nodarījumu būtību vai ietekmi vai ar nepieciešamību tos apkarot kopīgi.” 
Šādi rīkojoties, Parlaments izmantoja LESD 218. panta 11. punktā ietverto mehānismu, kas ir svarīgs divu apstākḷu dẹl. Pirmkārt, no juridiskā viedokḷa, jo saskaņā ar LESD 216. panta 2. punktu ES noslēgtie starptautiskie nolīgumi ir saistoši ES iestādēm un tās dalībvalstīm. Otrkārt, politiskajā ziņā, jo lūguma sniegt atzinumu iesniegšana pati par sevi rada iespējamus šķērṣ̌ı lus formālai nolīguma noslēgšanai. ${ }^{34}$

\section{Kompetenču sadales jautājums starp ES un dalībvalstīm}

Kompetenču sadalē starp ES un dalībvalstīm nedrīkst atkāpties no kompetences pieškiršanas principa (LES 5. panta 2. punkts), ievērojot, ka kompetence, kas nav pieškirta ES, paliek dalībvalsts zin̄ā (LES 4. panta 1. punkts). Stambulas konvencijas gadījumā ES nav piešķirta ekskluzīva kompetence pār visu šo konvenciju. Tas tā ir, jo Stambulas konvencija ir ES jaukts nolīgums. Arī Komisija savā priekšlikumā atzina: lai gan būtiskas Konvencijas daḷas un jo īpaši noteikumi attiecībā uz materiālajām krimināltiesībām un citi V nodalas noteikumi ir dalībvalstu kompetencē, ievērojama Konvencijas noteikumu dal̦a ietilpst ES kompetencē un tāpēc ES būtu jäparaksta Konvencija kopā ar dalībvalstīm. ${ }^{35}$

Juridiskā pamata izvēle var būt sarežğìta arī daudz vienkāršākos gadījumos, ${ }^{36}$ tomēr Stambulas konvencija ar tās plašo darbības jomu to padara īpaši komplicētu. N̦emot vērā, ka juridiskā pamata izvēlei ir konstitucionāla nozīme, ${ }^{37}$ tā jāveic, pamatojoties uz objektīviem kritērijiem, kurus var pārbaudìt tiesā..$^{38}$ Piemēram, Komisija savā priekšlikumā atsaucās uz dažādiem LESD noteikumiem par jomām, uz kurām attiecas Stambulas konvencija, t. i., LESD 16. pantu, LESD 19. panta 1. punktu, LESD 18., 21., 23., 46., 50., 78., 79., 81., 82., 83., 84., 157. pantu. Tomēr, tā kā Komisijas nostāja ir tāda, ka Stambulas konvencijas galvenais mērḳis ir aizsargāt sievietes, kuras ir cietušas no vardarbïbas, un novērst šādu vardarbību, kā juridisko pamatu tā ierosināja LESD 84. pantu kopā ar LESD 82. panta 2. punktu, kur pēdējā minētā tiesību norma neatšḳiras arī no Padomes izvēelētās.

Savukārt Padomes pieeja juridiskā pamata jautājumā atspoguḷo tās šauro izpratni par ES kompetencēm un to nodalǐšanu. Padome paredz Stambulas konvenciju parakstīt tikai par jautājumiem, kas saistîti ar tiesu iestāžu sadarbību krimināllietās, ${ }^{39}$ kā arī attiecībā uz patvērumu un neizraidīšanu. ${ }^{40}$ Padomes viedoklis balstìts uz pien̦ēmumu, ka Konvencija būtu jāparaksta ES vārdā attiecībā uz jautājumiem, kas ir ES kompetencē, tiktāl, ciktāl konvencija var ietekmēt ES kopīgos noteikumus vai maina to darbības jomu. Tas jo īpaši attiecas uz konkrētiem konvencijas noteikumiem saistībā ar tiesu iestäžu sadarbību krimināllietās un uz

\footnotetext{
${ }^{34}$ Cremona M. Opinions of the Court of Justice. In: Ruiz Fabri H. (ed.). Max Planck Encyclopaedia of International Procedural Law (MPEiPro), OUP, Oxford. Pieejams: online, paragraph 3.

$35 \operatorname{COM}(2016) 111$ final.

36 See, for instance, Koutrakos P. Legal Basis and Delimitation of Competence in EU External Relations. In: Cremona M. and De Witte B. (eds.). EU Foreign Relations Law - Constitutional Fundamentals (Hart Publishing, 2008) 171.

37 Opinion 2/00 (Cartagena Protocol on biodiversity), EU:C:2001:664, para. 5.

${ }^{38}$ Case C-263/14 European Parliament v Council (EU-Tanzania Transfer Agreement), EU:C:2016:43, para. 43.

39 Art. 1 Council Dec. 2017/865.

40 Art. 1 Council Dec. 2017/866.
} 
konvencijas noteikumiem saistībā ar patvērumu un neizraidīšanu. Dalībvalstis patur savu kompetenci tiktāl, ciktāl konvencija neietekmē kopigos noteikumus vai maina to darbïbas jomu. ${ }^{41}$ Tomēr uzsverams, ka šim apgalvojumam nav pievienota atsauce ne uz LESD 3. panta 2. punktu par ES kompetences ekskluzivitāti, ne arī uz LESD 216. panta 2. punktu par ES kompetences esamïbu. ${ }^{42}$

Šìs atšķirības starp ES iestāžu izpratni, kas izriet no iepriekš minētā, demonstrantē, kā Komisijas pamatotajam priekšlikumam seko šaurā Padomes pieeja. Turklāt, tā kā dalībvalstu starpā pastāv domstarpības par Stambulas konvencijas saturu un tās piemērošanas tvērumu, aktuāls kḷūst jautājums par savstarpēju vienošanos un lojālu sadarbību ne tikai starp ES dalībvalstīm, bet arī ES dalībvalstīm un ES iestādēm.

\section{Par savstarpēju sadarbību}

Dalïbvalstu starpā pastāv ievērojamas atškirīibas saistībā ar to pienākumu apjomu, kuru dalībvalstis gatavas uzņemties, tāpēc ārkārtīgi būtiski šo jautājumu skatīt no lojālas sadarbības principa viedokḷa, ko arī Parlaments lūdzis vērtēt EST.

Vispārēja kārtība, kādā jāslēdz starptautisks līgums, noteikta LESD 218. pantā. ${ }^{43}$ No minētās tiesību normas neatkāpjas arī EST. Piemēram, lietā C-28/12 Komisija/Padome EST konstatēja, ka ar Lēmumu 2011/708/ES ${ }^{44}$ tika atļauta attiecìgo nolīgumu parakstišana ES vārdā, kā arī paredzēta to provizoriska piemērošana. Šajā lietā EST norādīja, ka Padome un dalībvalstu valdību pārstāvji tiesību aktu, kas aţ̣auj parakstīt nolīgumu starp ES un trešajām valstīm vai starptautiskām organizācijām, un tiesību aktu par to, kā dalībvalstis provizoriski piemēro šo nolīgumu, nevar apvienot vienā lēmumā. Kā norādījusi EST, tas ir tādēl, ka dalïbvalstu kompetencē nav pieņemt pirmo lēmumu, un otrādi - Padomei kā ES iestādei nav nekādas nozīmes, pieñemot tiesību aktu par jauktā nolīguma provizorisku piemērošanu dalībvalstīs. Pēdējais minētais akts ir katras šìs valsts nacionālo tiesību kompetencē. Lìdz ar to EST nonāca pie secinājuma, ka lēmums neatbilst LESD 218. panta 2., 5. un 8. punktam un tādējādi arī LES 13. panta 2. punktam. ${ }^{45}$ Minētais liek secināt, ka dažădu procedūru sajaukšana un novirze no LESD 218. panta nav vēlama un atbalstāma. ${ }^{46}$

${ }^{41}$ Recital 6 of preamble to Council Dec. 2017/865 and Dec. 2017/866.

42 On the conceptual difficulties raised by the formulation of Arts 3(2) and 216(1) TFEU. Sk.: Baere G. de. Constitutional Principles of EU External Relations (OUP, 2008) 70, and Koutrakos P. EU International Relations Law $2^{\text {nd }}$ ed (Hart Publishing, 2015), pp. 126-130.

${ }^{43}$ Dashwood A., Dougan M., Rodger B., Spaventa E. and Wyatt D. Wyatt and Dashwood's European Union Law. $6^{\text {th }}$ ed. Hart Publishing, 2011.

${ }^{44}$ Padomes un Padomē sanākušo Eiropas Savienības dalïbvalstu valdỉbu pārstāvju 06.06.2011. Lēmums par to, lai Savienības vārdā parakstītu un provizoriski piemērotu Gaisa transporta nolīgumu starp Amerikas Savienotajām Valstīm, no vienas puses, Eiropas Savienību un tās dalïbvalstīm, no otras puses, Islandi, no trešās puses, un Norvēgijas Karalisti, no ceturtās puses; un par to, lai Savienības vārdā parakstìtu un provizoriski piemērotu papildnolīgumu starp Eiropas Savienību un tās dalïbvalstīm, no vienas puses, Islandi, no otras puses, un Norvēǵijas Karalisti, no trešās puses, par to, kā piemērot Gaisa transporta nolīgumu starp Amerikas Savienotajām Valstìm, no vienas puses, Eiropas Savienību un tās dalībvalstīm, no otras puses, Islandi, no trešās puses, un Norvēgijias Karalisti, no ceturtās puses. OJ L 283, 29.10.2011, pp. 1-2.

${ }^{45}$ Case C-28/12 Commission v Council, EU:C:2015:282, $\$ 41-53$.

${ }^{46}$ Sk.: Heliskoski J. The procedural law of international agreements: A thematic journey through Article 218 TFEU, (2020) 57 CMLRev, 113 at 90-4; Koutrakos P. Institutional Balance and Sincere Cooperation in 
Tāpat šajā kontekstā uzsverams, ka svarīgi izmantot tās tiesības, ko paredz Vīnes konvencija par starptautisko līgumu tiesībām, diferencējot valstu uzṇemto starptautisko saistību apjomu atkarībā no tā, vai valsts ir tikai parakstījusi starptautisku līgumu vai arī piekritusi tā saistošam raksturam, to ratificējot. Vīnes konvencijas 51. pants piešķir lielu nozīmi dalībvalstu neatkarīgajam lēmumam ratificēt starptautiskos līgumus. Minēto uzsvērusi arī Venēcijas komisija, ${ }^{47}$ kà arī generāladvokāts savos secinājumos. ${ }^{48}$

Pat apstākḷos, kad ES ir jau parakstījusi šo nolīgumu, Padome var atlikt savu lēmumu tik ilgi, cik tā uzskata par nepieciešamu, lai pieņemtu izsvērtu lēmumu. ${ }^{49}$ Tas tā ir vēl jo vairāk tādēl, ka ES, noslēdzot jauktu nolīgumu, atbilstoši starptautiskajām tiesībām var būt atbildīga par dalïbvalstu rīcību, lai arī dalībvalstis rīkotos savu ekskluzīvo kompetenču ietvaros. ${ }^{50}$

G̣enerāladvokāts savos secinājumos vērsa uzmanību uz šādu aspektu: ja viena vai vairākas dalībvalstis atteiktos noslēgt Stambulas konvenciju, Padome varētu, piemēram, nolemt, ka ES jāīsteno vairāk no sākotnēji paredzētās dalītās kompetences, lai tādējādi samazinātu pievienošanās apjomu, kas ietilpst dalībvalstu kompetencē ${ }^{51}$ G̦enerāladvokāts arī nonāca pie secinājuma, ka, ja dalībvalsts nav noslēgusi līgumu, tas neliedz tai ievērot ES principu par vienotību starptautiskajā pārstāvībā, ciktāl ar to šai valstij vienīgi ir noteikts pienākums atturēties no darbībām, kas acīmredzami ir pretējas ES pieṇemtajām nostājām. ${ }^{52}$ Vienlaikus generāladvokāts norādīja, ka dalībvalsts var izstāties no jaukta nolīguma, tomēr ši iespēja neuzliktu pienākumu arī ES atstāt nolīgumu. Padomei, generāladvokāta ieskatā, jāizvērtē kompromiss starp attiecīgā nolīguma nozīmīgumu un riskiem, ko rada tas, ka ES un dalībvalstis to noslēdz nepilnīgi. ${ }^{53} \mathrm{Lìd} z$ ar to generāladvokāts savos secinājumos nesniedz precīzu atbildi, vai Padomes konkrētā rīcība ir pareiza, tādēḷ ieteica tai nogaidìt, lai gan no LESD procedūras viedokḷ atzina, ka viss ir izdarìts pareizi.

\section{Kopsavilkums}

1. Ievērojot lojālas sadarbības principu, Padomei lēmums par starptautiskā līguma noslēgšanu no ES puses būtu jāpien,em pēc tam, kad to atbilstoši savām nacionālajām procedūrām apstiprinājušas visas ES dalībvalstis. Tomēr jāpatur prātā, ka vienlaikus LESD 218. panta 7. punktā noteikts, ka Padome lēmumus par starptautisko līgumu parakstišanu un pien̦emšanu pēc vispārīga noteikuma var pieņemt ar kvalificētu balsu vairākumu.

treaty-making under EU law. (2019) 68 ICLQ 13-16.

47 Venice Commission Opinion 961/2019 "Opinion on the constitutional implications of the ratification of the Council of Europe Convention on Preventing and Combating Violence against Women and Domestic Violence (Istanbul Convention) (Armenia)". Council of Europe doc. CDLAD(2019)018, p. 3.

48 EST 20.11.2018. spriedums apvienotajās lietās 626/15 un C-659/16 Komisija/Padome (AJT Antarktika), EU:C:2018:925, 127. punkts.

49 G̦enerāladvokāta 11.03.2021. secinājumi lietā Avis 1/19, EU:C:2021:198, 202., 203. punkts.

50 Turpat, 205. punkts.

51 EST 20.11.2018. spriedums apvienotajās lietās C-626/15 un C-659/16 Komisija/Padome (AJT Antarktika), EU:C:2018:925, 126. punkts.

52 G̦enerāladvokāta 11.03.2021. secinājumi lietā Avis 1/19, EU:C:2021:198, 223. punkts.

53 Turpat, 225. punkts. 
2. Uz ES, gluži tāpat kā uz jebkuru citu konvencijas pusi, attieksies uzraudzības mehānisms, t. i., tas attieksies uz visām ES iestādēm, struktūrām, birojiem un ag̉entūrām. Tas tā ir, jo ES nevar izslēgt no Stambulas konvencijas piemērošanas jomas ES iestādes, struktūras, birojus un agentūras. Tomēr Komisija savos priekšlikumos minēto vispār nav aplūkojusi, kā arī nav vērtējusi šo jautājumu, lai gan tas skar pienākumus, kurus faktiski ES grasās uzṇemties.

3. ES dalībvalstu starpā nav vienotas izpratnes par to, kā būtu Stambulas konvencijas jāpiemēro vai jāinterpretē. Lìdz ar to vēl jo aktuālāks kḷūst jautājums par ES rīcības, pievienojoties Stambulas konvencijai bez visu tās dalībvalstu piekrišanas, saderību ar to, ka katrai valstij ir tiesības un brīvïba noslēgt starptautiskos lìgumus.

4. Dalībvalstu starpā pastāv ievērojamas atšķirības saistībā ar to pienākumu apjomu, kuru dalībvalstis gatavas uzṇemties, tāpēc ārkārtīgi būtiski šo jautājumu skatīt no lojālas sadarbības principa viedokḷa.

5. Svarīgi izmantot tās tiesības, ko paredz Vīnes konvencija par starptautisko līgumu tiesībām, diferencējot valstu uzṇemto starptautisko saistību apjomu atkarībā no tā, vai valsts ir tikai parakstījusi starptautisku līgumu vai arī piekritusi tā saistošam raksturam, to ratificējot. Vīnes konvencijas 51. pants piešksir lielu nozīmi dalībvalstu neatkarīgajam lēmumam ratificēt starptautiskos ligumus. 